\title{
$\mathrm{TbFeCo}$ 薄膜における有効元素量と磁気物性の相関
}

\author{
原亮介1,* \\ 山根治 起 $^{2}$ \\ 伊佐地育圭 ${ }^{3}$ \\ 小林 政 信 \\ 森迫 昭光 ${ }^{5}$ \\ 劉 小 晰 ${ }^{5}$ \\ 安川雪子 ${ }^{6}$
}

${ }^{1}$ 千葉工業大学工学研究科電気電子情報工学専攻
${ }^{2}$ 秋田県産業技術センター電子光応用開発部
${ }^{3}$ 千葉工業大学工学研究科工学専攻
${ }^{4}$ 千葉工業大学工学部先端材料工学科
${ }^{5}$ 信州大学工学部電子情報システム工学科
${ }^{6}$ 千葉工業大学工学部電気電子工学科

J. Japan Inst. Met. Mater. Vol. 82, No. 5 (2018), pp. 140-146

(C) 2018 The Japan Institute of Metals and Materials

\section{Correlation between the Effective Amounts of Elements in TbFeCo Thin Films and Their Magnetic Properties}

Ryosuke Hara ${ }^{1, *}$, Haruki Yamane ${ }^{2}$, Yasuyoshi Isaji ${ }^{3}$, Masanobu Kobayashi ${ }^{4}$, Akimitsu Morisako ${ }^{5}$, Xiaoxi Liu ${ }^{5}$ and Yukiko Yasukawa ${ }^{6}$

${ }^{1}$ Graduate School of Engineering, Department of Electrical, Electronics and Computer Engineering, Chiba Institute of Technology, Chiba 275-0016

${ }^{2}$ Division of Electronic Light Application and Development, Akita Industrial Technology Center, Akita 010-1623

${ }^{3}$ Graduate School of Engineering, Chiba Institute of Technology, Chiba 275-0016

${ }^{4}$ Department of Advanced Materials Science and Engineering, Faculty of Engineering, Chiba Institute of Technology, Chiba 275-0016

${ }^{5}$ Department of Electrical and Computer Engineering, Faculty of Engineering, Shinshu University, Nagano 380-8553

${ }^{6}$ Department of Electrical and Electronic Engineering, Faculty of Engineering, Chiba Institute of Technology, Chiba 275-0016

In this study, TbFeCo thin films were prepared using DC-magnetron sputtering technique utilizing a conventional batch-type sputtering machine. The magnetic properties such as magnetic hysteresis loops and magneto-optical properties of the obtained films were measured. Furthermore, we precisely evaluated the "effective" amounts of elements, i.e., the amounts of constituents released by oxidation, in $\mathrm{TbFeCo}$ thin films. We also attempted to control the amounts of effective elements by changing the pre-sputtering condition before film preparation. This is because the pre-sputtering process greatly affected the effective amounts of elements in the prepared $\mathrm{TbFeCo}$ thin films, such that the magnetic properties were drastically different from sample to sample by altering the pre-sputtering condition. Insufficient pre-sputtering led to a relatively high oxygen content in the films in comparison with those prepared with sufficient pre-sputtering. Outstanding perpendicular magnetic anisotropy in the out-of-plane direction was observed in a film prepared after $60 \mathrm{~min}$ of pre-sputtering, which exhibited a coercivity $\left(H_{c \perp}\right)$ value of $6.4 \mathrm{kOe}$ from magnetic hysteresis measurements and $8.2 \mathrm{kOe}$ from magneto-optical polar Kerr hysteresis measurements at an incident light of wavelength $700 \mathrm{~nm}$. The saturation value of the polar Kerr rotation angle $\left(\theta_{\mathrm{K}}\right)$ of this film was approximately $0.3^{\circ}$, which is comparable to the theoretically optimized value. Therefore, we demonstrated that high-quality TbFeCo films can be obtained with high reproducibility by using a simple batch-type sputtering machine and that there is a strong correlation between effective amounts of elements in TbFeCo thin films and their magnetic properties. [doi:10.2320/jinstmet.J2017041]

(Received September 14, 2017; Accepted January 25, 2018; Published March 2, 2018)

Keywords: terbium iron cobalt magnetic thin film, magnetic property, magneto-optical polar Kerr effect, effective amounts of elements, oxidation

1. 緒言

$\mathrm{TbFeCo}$ 薄膜は室温で高保磁力の優れた垂直磁気異方性を 示すアモルファス材料であり, 他の磁性材料と比較し室温に おいて大きな Kerr 回転角 $\left(\theta_{\mathrm{K}}\right)$ を示す ${ }^{1)}$ ことから, かつて光磁 気記録媒体用材料として広く研究され，実用されてきた ${ }^{2)}$.

\footnotetext{
* 千葉工業大学大学院生 (Graduate Student, Chiba Institute of Technology)
}

$\mathrm{TbFeCo}$ 薄膜は $4 f$ 元素である $\mathrm{Tb}$ と, $3 d$ 元素である $\mathrm{Fe}$ および Co の反平行の磁気モーメントの大きさが揃う補償点近傍組成 において垂直磁気異方性が発現する ${ }^{3)}$ が, 補償組成からずれ ると垂直磁気異方性や保磁力 $\left(H_{c}\right)$ が劣化する $^{3,4)}$. 補償点近傍 組成の垂直磁化膜を作製するには綿密な組成制御が不可欠で あり，様々な方法による組成制御がこれまでに試みられてき た $^{1,4)}$. TbFeCo 薄膜は近年ではスピントロニクスデバイスへ の応用を目指した強磁性ナノワイヤ ${ }^{5,6)}$ や, 垂直磁気ランダム アクセスメモリの開発7)に向け垂直磁気トンネル接合などに 
用いられている材料である。我々は $\mathrm{TbFeCo}$ 薄膜と貴金属ナ ノ粒子の複合材料について研究しており，貴金属ナノ粒子の 局在表面プラズモン共鳴による効果を利用して TbFeCo 薄膜 の磁気物性の変調と制御・向上に関する研究を行っている.

しかし構成元素のうち特に $\mathrm{Tb}$ は非常に酸化されやすく, 高 品位な TbFeCo の成膜条件が安定しない。すなわち酸化によ る薄膜の $H_{c}$ や $\theta_{\mathrm{K}}$ の減少をはじめとする磁気物性の劣化は, 材料として克服すべき課題の一つである，そのため $\mathrm{TbFeCo}$ や $\mathrm{TbFe}$ 系薄膜では元素添加 ${ }^{8,9}$ や保護膜 ${ }^{10)}$ による垂直磁気異 方性の安定化が研究されてきた。 また垂直磁気異方性の安定 した発現には，ロードロック方式を用いた高真空環境下での 薄膜の酸化抑制が必須とされ，プロセスコストが高い点も課 題の一つである。 さらに $\mathrm{TbFeCo}$ を含む希土類 - 遷移金属ア モルファス合金系薄膜の垂直磁気異方性の発現メカニズムは 複雑である。これらの問題点により $\mathrm{TbFeCo}$ 薄膜の磁気物性 の厳密制御は困難で, 試行錯誤を経て最適に近い成膜条件を 採用するため, 研究グループによる実験環境の違いに起因し た結果のばらつき11,12)も問題として挙げられる.

本研究は単層の $\mathrm{TbFeCo}$ 薄膜に焦点を絞った研究である. ターゲットと組成調整用の $\mathrm{Tb}$ チップに対する成膜前のプレ スパッ夕条件の違いにより, 膜中の酸化されていない元素 $(\mathrm{O}$ と未結合で, 純粋な単体として存在する元素. これを「有効元 素」と表記する)の量の変化を厳密に制御・評価した。すなわ ち元素添加や保護膜形成などの外因的な手段ではなく, プレ スパッタ条件の制御のみで $\mathrm{TbFeCo}$ 薄膜の酸化抑制をとおし た有効元素量の制御を試みた。 その上で，有効元素量と磁気 物性の相関を実験的に検証し議論した。

従来の研究では, 酸化されて $\mathrm{O}$ と結合した元素も, $\mathrm{O}$ と未 結合の有効元素も区別されず，一緒くたに膜中の元素として 見なされてきた。つまり一緒くたの元素量と磁気物性の相関 に関する研究であるのに対し, 我々は磁気物性, 特に TbFeCo の本質的な磁気光学特性に寄与するのは薄膜中の有効元素の みであることに着目した，具体的には成膜前のプレスパッタ 条件のみをパラメータとして TbFeCo 薄膜を作製し, 磁気特 性と磁気光学特性の結果から有効元素量について包括的に議 論し, 磁気物性と有効元素量の相関を考察した。この視点に 基づく研究は我々が知る限り本研究が初めてである.

また本研究ではプロセスコストの低減を目指し, 簡便・安 価で汎用性の高いバッチ式一源スパッタ装置を用いて優れた 磁気物性を示す $\mathrm{TbFeCo}$ 薄膜の成膜条件の確立も目的とした. $\mathrm{TbFeCo}$ 薄膜の革新的な応用を目指した材料設計を行う上で は，有効元素量の制御，有効元素量と磁気物性の関係の解明 および容易に再現性良く高品位な成膜条件を確立することが キーポイントである。

\section{2. 実 験 方 法}

\section{1 試料作製}

バッチ式一源マグネトロンスパッタ装置 ((株) ULVAC, SBR1104 をスタマイズ)を用いて $\mathrm{TbFeCo}$ 薄膜をガラス基板 (Corning Inc., EAGLE XG, 33〜35 $\mathrm{mm} \times 25 \mathrm{~mm} \times 0.5 \mathrm{~mm}$ ) 上 に成膜した。成膜に先立ちガラス基板は超純水で 2 回, イソ
プロピルアルコールで 1 回, 各10分間ずつ計 30 分間, 超音波 を照射して洗浄した．スパッタチャンバーの到達圧力は1.33〜 $2.67 \times 10^{-4} \mathrm{~Pa}$ であり, 成膜前のターゲットと $\mathrm{Tb}$ チップの清 浄化を目的としたプレスパッ夕時間を様々に変化させて $\mathrm{TbFeCo}$ 薄膜を作製した。 プレスパッタ時の $\mathrm{Ar}$ ガス圧とス パッタパワー密度はそれぞれ $4.00 \times 10^{-1} \mathrm{~Pa}, \quad 0.12 \mathrm{~W} / \mathrm{cm}^{2}$ と し，プレスパッタ時間を $3 \sim 120$ 分の間で変化させた.

プレスパッタを施した後, TbFeCo 合金ターゲット (豊島製 作所(株), $\mathrm{Tb}: \mathrm{Fe}: \mathrm{Co}=22: 66: 12 \mathrm{at} \%)$ 上に Tb チップ(日 本イットリウム(株), $10 \mathrm{~mm} \times 10 \mathrm{~mm} \times 1 \mathrm{~mm}$ ) を配置した複 合ターゲット方式により膜厚 $65 \mathrm{~nm}$ の薄膜を成膜した。 $\mathrm{Tb}$ チップはアセトンで 1 回, イソプロピルアルコールで 1 回, 各10分間の超音波洗浄の後に使用した．DCスパッタ法(200〜 $250 \mathrm{~V}, 0.04 \sim 0.05 \mathrm{~A}, 10 \mathrm{~W})$ で $\mathrm{Ar}$ ガス圧 $4.00 \times 10^{-1} \mathrm{~Pa}$ の環境下 において，成膜速度 $0.02 \sim 0.04 \mathrm{~nm} / \mathrm{s}$ にて薄膜を作製した。 な おプレスパッタと同様, 成膜時のスパッタパワー密度は 0.12 $\mathrm{W} / \mathrm{cm}^{2}$ とした，本研究では成膜前のプレスパッ夕時間以外は すべての試料において同一条件下で薄膜を成膜した。

\section{2 試料評価}

成膜後, 直ちに振動試料型磁力計 (VSM : 東英工業 (株), C7-10A)を用いて室温における磁気特性を評価した。最大印 加磁界を $\pm 10 \mathrm{kOe}$ とし, 磁化校正には高純度ニッケル (東英 工業(株))を用い, 試料は高純度ニッケルと同じ形状・サイズ になるよう $8 \mathrm{~mm} \times 8 \mathrm{~mm}$ に切断して測定した. 蛍光 $\mathrm{X}$ 線分 析法(XRF：エポリードサービス(株), SEA1200VX)より, 特 に薄膜中の $\mathrm{Tb}$ 含有量を中心として膜の組成を定量した。膜 厚は原子間力顕微鏡 (AFM: KEYENCE Corp., VN-8010)で測 定した. X 線光電子分光法 (XPS: ULVAC-PHI Inc., PHI5000 Versa Probe) を用いて加速電圧を $1 \mathrm{kV}$ とし, 試料表面から 1 回につき約 $0.66 \mathrm{~nm}$ ずつスパッタエッチングと元素の測定を 21回繰り返し, 薄膜の深さごとの元素の化学結合状態を検証 した. XPS スペクトルの面積は専用解析ソフトウェア MultiPak V9 (ULVAC-PHI Inc.) から算出した。 また, 最大印加磁界 $\pm 15 \mathrm{kOe}, 250 \sim 900 \mathrm{~nm}$ の入射光に対する $\theta_{\mathrm{K}}$ を紫外分光式 磁気特性評価装置 (ネオアーク(株), BH-M800UV-HD-10)で 測定し, 磁気光学特性を評価した.

\section{3. 実験結果および考察}

\section{1 結晶性および磁気特性}

プレスパッタを60分施した膜厚 $65 \mathrm{~nm}$ の TbFeCo 薄膜の X 線回折パターンを Fig. 1 に示す.一般的に TbFeCo はアモル ファスであるが, 成膜条件によっては結晶化することがある. しかし本研究では結晶に由来する回折ピークは観察されずハ ローパターンのみが観察されたため, 試料はアモルファスで ある。

成膜前のプレスパッタ時間をパラメータとした際の磁気特 性を Fig. 2 に示す。この結果は膜面に対して垂直方向に外部 磁界を印加した際の磁化 $(M)$ 変化であり, 規格化した $M$ で表 している. $\mathrm{TbFeCo}$ 薄膜の成膜条件が同一にもかかわらず，成 膜前のプレスパッ夕時間を $3 \sim 120$ 分に変化させた結果, 磁気 


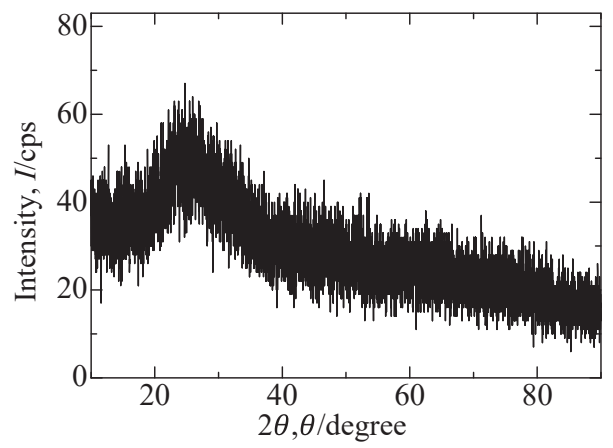

Fig. 1 X-ray diffraction pattern of a TbFeCo film with a thickness of $65 \mathrm{~nm}$.

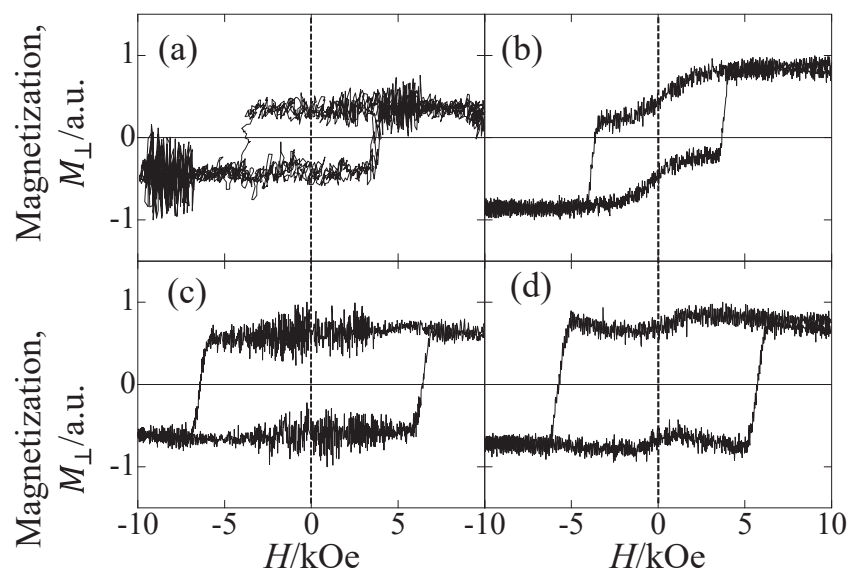

Fig. 2 Out-of-plane magnetic hysteresis loops of TbFeCo films measured at room temperature. The pre-sputtering time before film preparation was (a) 3, (b) 20, (c) 60, and (d) $120 \mathrm{~min}$. After the pre-sputtering, TbFeCo films were prepared under the same experimental conditions for all samples; namely, a sputtering power density of $0.12 \mathrm{~W} / \mathrm{cm}^{2}$ and an Ar gas pressure of $4.00 \times 10^{-1} \mathrm{~Pa}$. Note that the $\mathrm{y}$-axis represents the normalized values.

特性に明瞭な違いが見られた. プレスパッタ 3 分 (Fig. $2(\mathrm{a}))$, 20分 (Fig. 2(b))の試料では $H_{c \perp}$ が約 $3.7 \mathrm{kOe}$ であったが，プ レスパッタ60分 (Fig. 2(c)), 120分 (Fig. 2(d))の試料では $H_{c \perp}$ がそれぞれ約 $6.4 \mathrm{kOe} ， 5.7 \mathrm{kOe}$ であり，プレスパッ夕時間の 伸長に伴い $H_{c \perp}$ が増大し優れた垂直磁気異方性を発現する傾 向が見られた．20分，120分の試料において磁化曲線に僅かな ねじれが観察された. TbFeCo 薄膜では低スパッタパワーで 成膜した際にねじれが報告されており ${ }^{13)}$ ，本研究では 0.12 $\mathrm{W} / \mathrm{cm}^{2}$ と非常に低いスパッタパワーで成膜したため磁化曲線 にねじれが見られたのではないかと考える.

$\mathrm{TbFeCo}$ の磁気特性は特に薄膜中の $\mathrm{Tb}$ 量によって著しく変 化することが知られている ${ }^{3)}$ ため, Fig. 3(a)にプレスパッタ 時間に対する蛍光 $\mathrm{X}$ 線分析法で求めた薄膜中の $\mathrm{Tb}$ 含有量 (

と, Fig. 2 から求めた $H_{c \perp}(\triangle)$ の関係を示す. いずれの試料 においても膜中の $\mathrm{Tb}$ 量は約 26 at\%であった一方で, 60分以 上プレスパッタを施すと $H_{c \perp}$ が増加しており，60分以上のプ レスパッタは $\mathrm{TbFeCo}$ 薄膜の垂直磁気異方性の発現に有効な ことがわかる。 また飽和磁化 $\left(M_{s}\right)$ の值は，プレスパッ夕時間 とともに薄膜垂直方向 $(\triangle)$ も面内方向 $($ ) も減少した $($ Fig. 3 (b)). 一般的に相反する磁気モーメントの大きさが揃う $\mathrm{TbFeCo}$ の補償点では, 膜全体の $M$ の值が 0 になる一方で

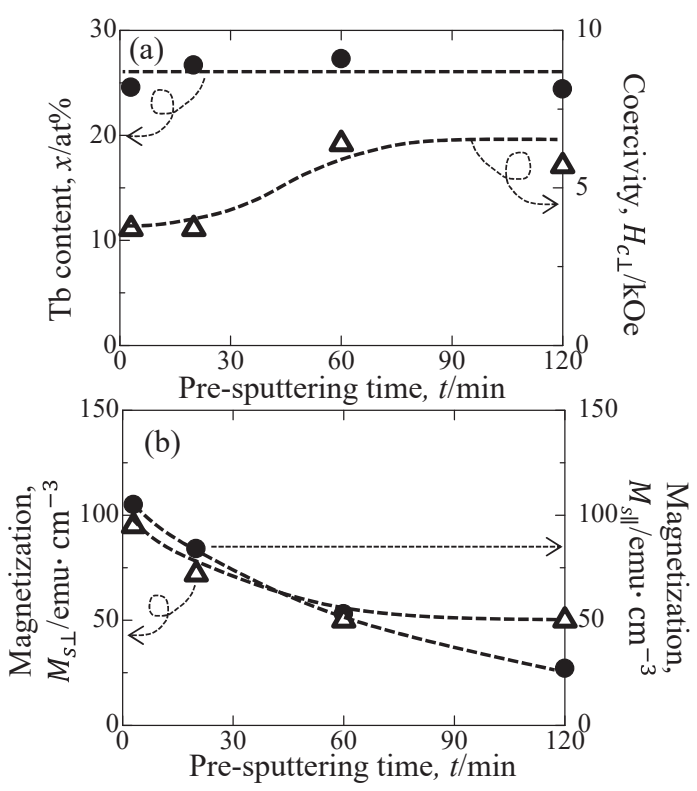

Fig. 3 (a) Dependence of Tb contents (-) in the films and out-of-plane coercivity $\left(H_{c \perp}\right)$ values $(\triangle)$ on the pre-sputtering time. (b) Changes in the saturation magnetization values as a function of pre-sputtering time. $\triangle$ : Out-of-plane, and $\mathbf{O}$ : inplane magnetizations.

$H_{c \perp}$ は無限大となる ${ }^{3,4)}$. 従ってプレスパッタを60分以上施し てから成膜した試料は $H_{c \perp}$ が 5.7〜 6.4 kOe (Fig. 3(a)) と大き いが， $M_{\perp}$ と $M_{/ /}$が 25〜 $50 \mathrm{emu} / \mathrm{cm}^{3}$ と相対的に小さいため (Fig. 3(b)), 補償点近傍組成の薄膜であると推測できる.

この結果は成膜条件そのものではなく, ターゲットと $\mathrm{Tb}$ チップを清浄化するプレスパッタにより薄膜中の $\mathrm{Tb}$ の酸化 状態が影響されて磁気特性が顕著に変化したと考えられる. プレスパッタを 60 分以上施した試料はターゲットと Tb チッ プが十分に清浄化され，Tbをはじめとする薄膜中の元素が有 効元素の状態で多く存在し, 補償点近傍の組成が得られたと 考えた。しかし $\mathrm{TbFeCo}$ は薄膜中の有効 $\mathrm{Tb}$ 量が約 22 at\%で

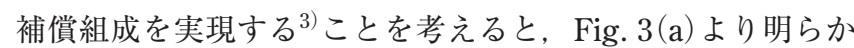
となった $\mathrm{Tb}$ 量 $(26 \mathrm{at} \%)$ は補償組成の有効 $\mathrm{Tb}$ 量より多いこと になる。 そこで次に薄膜の有効元素量について詳細な実験を 行った.

\section{2 薄膜中の有効元素量}

XPS により 1 回につき約 $0.66 \mathrm{~nm}$ (約 $0.59 \mathrm{~nm} / \mathrm{min}$ )のス パッタエッチングを繰り返し, 各層ごとの元素の化学結合状 態を調べた. Tb $4 d$, Fe 2 $p_{3 / 2}$, Co $2 p_{3 / 2}$ の XPS ピーク面積の合 算值 $(\triangle)$ と， O $1 s$ のピーク面積 $(\boldsymbol{O})$ の比較を Figs. $4(\mathrm{a}), 4$ (b)に示す. Fig. 4(a)はプレスパッ夕 3 分, Fig. 4(b)は60分の 結果を表す。ここでは絶対值ではなく規格化した值で比較を 行った.いずれも膜深部では薄膜中の金属元素 $(\mathrm{Tb}, \mathrm{Fe}, \mathrm{Co})$ が増加し, O が減少する傾向が見られ, 膜深部で有効元素量 が増加している. Fig. 4(c)には専用解析ソフトウェア MultiPak V9を用いた O 1sのピーク面積の算出例を示す。本研究で は得られたピークのバックグラウンドを差し引いた上で面積 をソフトウェアで計算した。 プレスパッタ60分の試料につい て, Fe $2 p_{3 / 2}(\bigcirc)$ と Co $2 p_{3 / 2}(\triangle)$ のピーク面積の比較を Fig. 5 に示す。どちらのピーク面積も膜深部になるにつれて増加し 

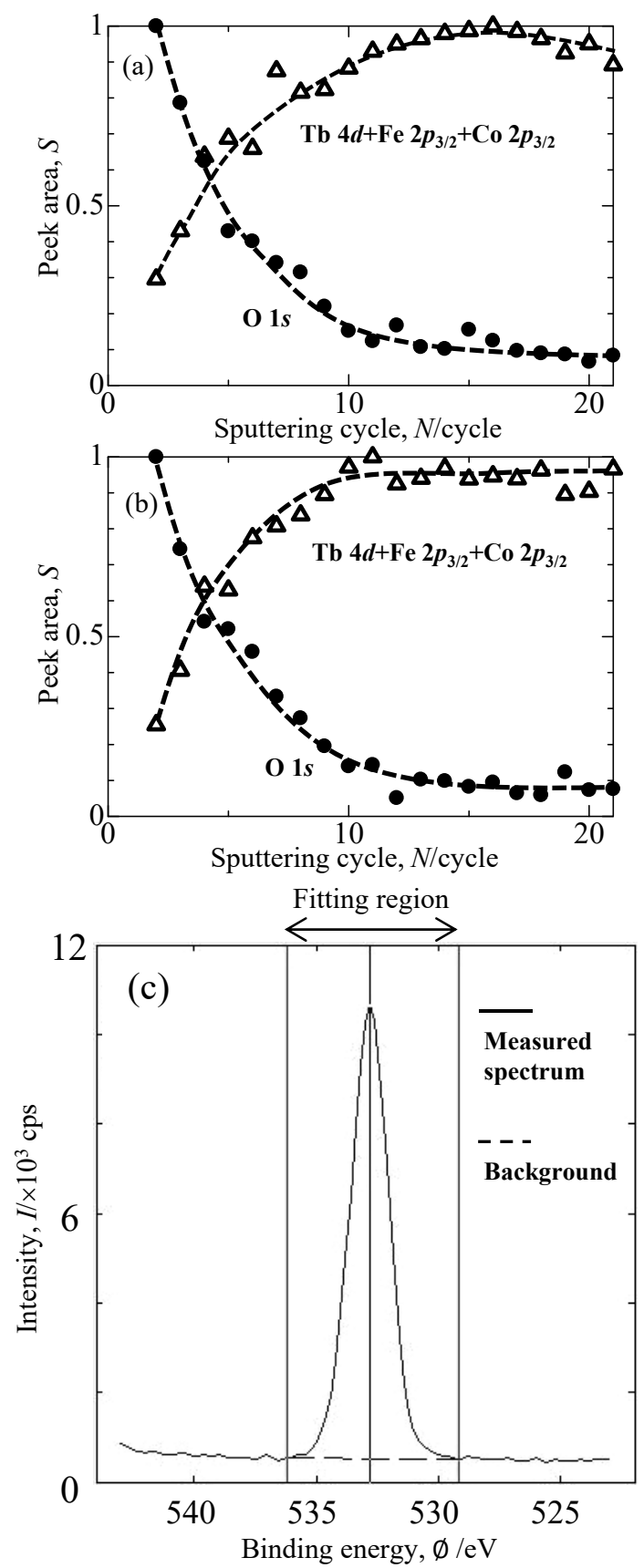

Fig. 4 Changes in the chemical bonding states of TbFeCo films measured by X-ray photoelectron spectroscopy as a function of the sputtering cycle, i.e., film depth. $\mathbf{O}$ : Normalized peak areas of $\mathrm{O} 1 s, \triangle$ : normalized peak areas of the sum of $\mathrm{Tb} 4 d, \mathrm{Fe} 2 p_{3 / 2}$, and Co $2 p_{3 / 2}$. The pre-sputtering time was (a) 3 and (b) 60 min. (c) Example for the determination of the XPS peak area of O $1 s$ using the "MultiPak V9" software.

た。これは膜の深部になるほど $\mathrm{O}$ と未結合の有効 $\mathrm{Fe}$ 量と有 効 Co 量が増加することを示し, この結果は膜深部で $\mathrm{O}$ が減 少する Fig. 4 の結果と一致する.ささらに Fe $2 p_{3 / 2}$ はスパッタ エッチング10層目から, Co $2 p_{3 / 2}$ はスパッタエッチング 9 層目 からピーク面積が凡そ一定となった。すなわち $\mathrm{O}$ と未結合の Fe と Co が存在しているのは, それぞれスパッタエッチング 10層目と 9 層目より膜深部であることを示唆する。これはそ れぞれ膜表面から約 $6.6 \mathrm{~nm}$ と約 $5.9 \mathrm{~nm}$ に相当する。逆に, 膜表面から Fe は約 $6.6 \mathrm{~nm}, \mathrm{Co}$ は約 $5.9 \mathrm{~nm}$ が部分的に酸化 していると考えられる.

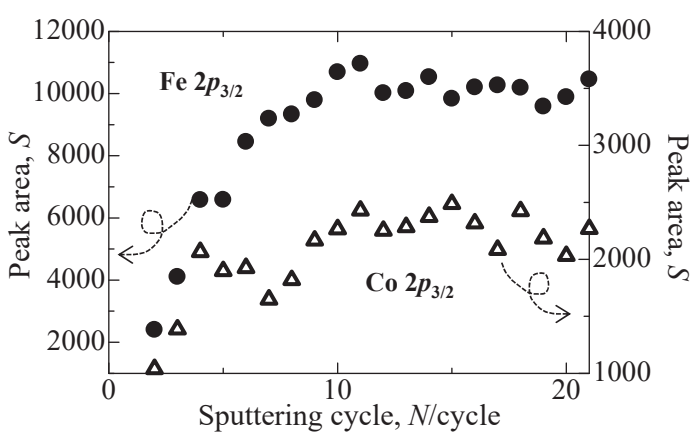

Fig. 5 Peak areas of Fe $2 p_{3 / 2}(\bigcirc)$ and Co $2 p_{3 / 2}(\triangle)$ as a function of film depth obtained by XPS measurements.

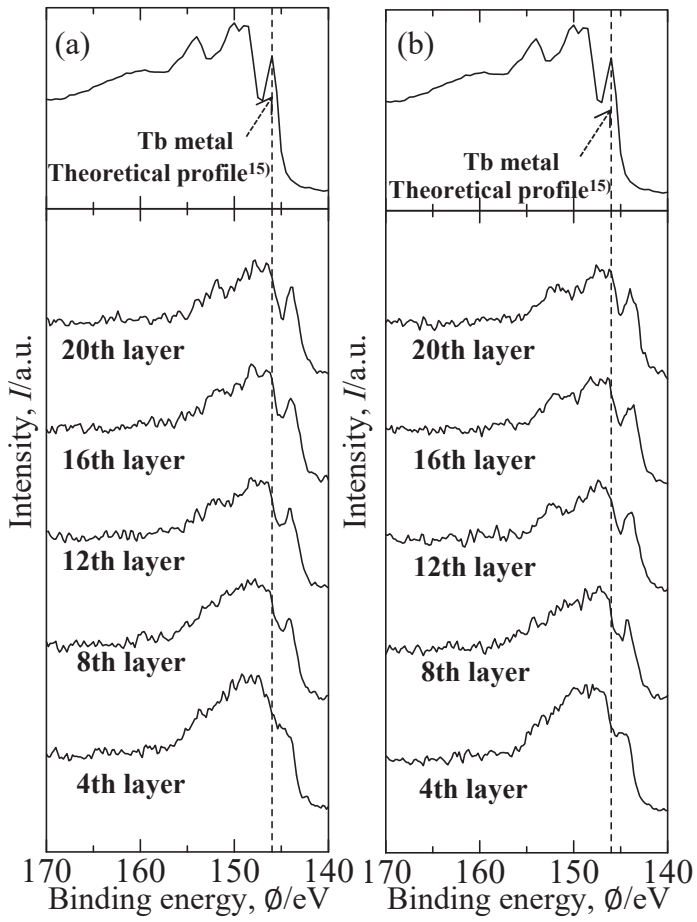

Fig. 6 XPS spectra of Tb $4 d$ for various depths of TbFeCo films. The pre-sputtering time was (a) $3 \mathrm{~min}$ and (b) $60 \mathrm{~min}$.

構成元素のうち最も酸化されやすいのは $\mathrm{Tb}$ であるため ${ }^{14)}$, $\mathrm{O}$ と $\mathrm{Tb}$ の結合状態を詳細に解析した。 プレスパッタ 3 分と 60分の試料について, Tb 4d の XPS プロファイルをスパッタ エッチング層ごとに比較した結果を Figs. 6(a)，6 (b)に示す. 図中に矢印で示す $\mathrm{Tb} 4 d$ のピークは $\mathrm{O}$ と未結合で純粋な $\mathrm{Tb}$ 元素を表すピークであり, MultiPak V9を用いてこのピークの 面積を計算することにより膜中の酸化されていない有効 $\mathrm{Tb}$ 量を評価できる。図中の破線はデータベース ${ }^{15)}$ に基づく $\mathrm{Tb}$ $4 d$ のピーク位置を表す. Tb $4 d$ のピークは，いずれの試料・ 層においても低エネルギー側へのシフトが見られた. Fe $2 p_{3 / 2}$ と Co $2 p_{2 / 3}$ のプロファイルについても同様に低エネルギー側 へのシフトが観察されたため, このシフトは試料のチャージ アップが原因と考えられる. Figs. 6(a)，6(b)より，どちら の試料も膜表層側であるスパッタエッチング 4 層目は $\mathrm{Tb} 4 d$ のピークは不明瞭である。これは測定前に試料を大気曝露し たことによる膜表面の自然酸化が原因と思われる。一方，明 瞭な $\mathrm{Tb} 4 d$ のピークを確認できたのはどちらの試料もスパッ 
タエッチング 8 層目，すなわち表面から約 $5.3 \mathrm{~nm}$ より深部で あった．特にスパッタエッチング12層目（表面から〜 7.9 nm) より膜深部では, $\mathrm{Tb} 4 d$ 本来のプロファイル形状 ${ }^{15)}$ と類似し ている.よって $\mathrm{O}$ と未結合な $\mathrm{Tb}$ が存在するのはスパッタエッ チング12層目より深部であると判断した. この結果より $\mathrm{Tb}$ は表面から約 $7.9 \mathrm{~nm}$ が部分酸化されていると考えられる.

次に Tb $4 d$ とO $1 s$ のピーク面積を比較した (Fig. 7). Fig. 7 (a)において, Tb $4 d$ についてプレスパッタ 3 分 $(\mathbf{O})$ と60分 $(\triangle)$ の試料のピーク面積を比較すると, どちらもスパッ夕 エッチング回数の増加に伴い有効 $\mathrm{Tb}$ 量が増加したため, 膜 深部になるにつれ有効 $\mathrm{Tb}$ 量は増加する. Fig. 7(a)の挿入図 は，XPS のスパッタエッチング 8 層目 (表面から〜 $5.3 \mathrm{~nm}$ ) か ら21層目 (表面から〜13.9 nm)までの Tb $4 d$ のピーク面積を表 す. 挿入図から求めたプレスパッタ 3 分の近似関数(破線)は $y=1.76 x+3.28$ で表され, 相関係数 $|r|$ は 0.756 あ゙あた. 一方, プレスパッタ 60 分では破線で表した近似関数は $y=2.33 x+$ 1.20 で $|r|$ は0.926であった. 図よりプレスパッ夕60分の方が 3 分の試料よりも Tbのピーク面積が大きく, これは近似関数 を比較しても明らかである．従ってプレスパッタ60分の方が 3 分の試料よりも有効 $\mathrm{Tb}$ 量が多いことが明らかとなった．以 上より, プレスパッタ 3 分ではターゲットと $\mathrm{Tb}$ チップ表面 の清浄化が不十分なため膜中に $\mathrm{Tb}_{2} \mathrm{O}_{3}$ が存在すると考えられ, その結果プレスパッタ 3 分と 60 分の試料では Figs. $2(\mathrm{a}), 2$ (c)に示したように磁気特性に大きな相違が見られたと考えら れる.

同様に O $1 s$ の面積についてもプレスパッタ 3 分 $(\mathbf{O})$ と60分
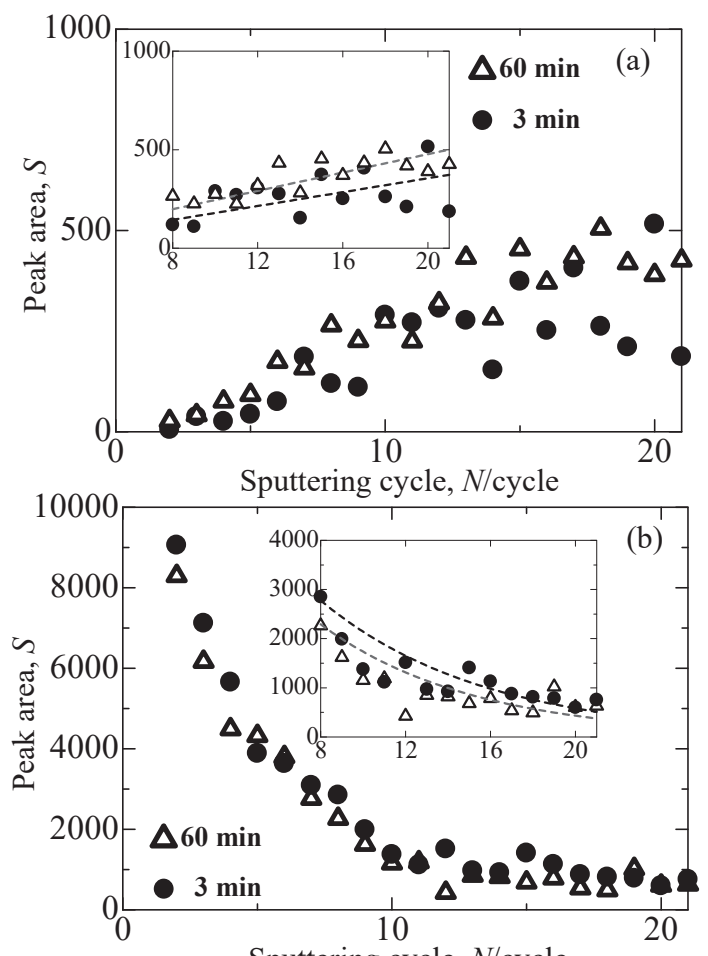

Sputtering cycle, $N /$ cycle

Fig. 7 XPS peak areas of (a) Tb $4 d$ and (b) O $1 s$ as a function of film depth. TbFeCo films were prepared after $3(\mathbf{O})$ and 60 $\min (\triangle)$ of pre-sputtering in both figures. The insets show the partial results for sputtering cycles from 8 times up to 21 times. The broken lines show the mathematical approximations mentioned in the text. $(\triangle)$ の試料を比較した結果を Fig. 7(b)に示す. Fig. 7(a) と同 様, 挿入図はXPS のスパッタエッチング 8 層目から 21 層目ま での $01 s$ のピーク面積を表す。どちらの試料もスパッタエッ チング回数の増加に伴い $\mathrm{O}$ の顕著な減少が見られた。プレス パッタ 3 分の場合, 抻入図より算出した近似関数(破線) は $y=$ $7856.4 e^{-0.13 x}$ で $|r|=0.895$ となり，プレスパッタ 60 分では近似関

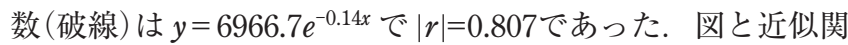
数を比較すると, プレスパッタ 3 分の方が 60 分の試料よりも ピーク面積が大きく，従ってプレスパッタ 3 分の試料の方が 膜中の $\mathrm{O}$ 量が多い. Fig. 7より明らかとなった膜深部になる ほど O が減少する結果は, Fig. 4の結果と一致する。 ピーク 幅, ピーク強度ともに Tb $4 d$ の方が $\mathrm{O} 1 s$ より遥かに小さいた め, Fig. 7では Tb $4 d$ の面積の絶対值が O $1 s$ のそれに比べ著 しく小さくなっている.

一連のXPSの結果よりプレスパッタ 3 分と60分の試料では, $\mathrm{Tb}, \mathrm{Fe}, \mathrm{Co}$ に対する O の結合状態が異なることが明らかと なった。特に容易に酸化される Tbについては, ターゲット と $\mathrm{Tb}$ チップを十分に清浄化すると有効 $\mathrm{Tb}$ 量が増加する (Figs. 6, 7 ). 本研究の成膜条件下では, 成膜後にチャンバーを大 気開放して試料を取り出し, 次の成膜のため再びチャンバー を真空引きする．この間にターゲットと Tbチップが酸化さ れると推測する。 そのため短時間のプレスパッタではター ゲットと $\mathrm{Tb}$ チップの酸化部分を除去しきれないが，60分以 上のプレスパッタでは除去することができ，その結果，プレ スパッ夕時間によって膜中の有効 $\mathrm{Tb}$ 量が異なると考えられ る.

\section{3 磁気光学特性}

プレスパッタ 3 分および60分の試料について, 磁気 Kerr効 果に起因する極 Kerr 回転角 $\theta_{\mathrm{K}}$ を測定した. TbFeCo 薄膜の 極 Kerr 効果は光源波長700 nm 近傍で応用されるため ${ }^{10,13,16)}$, 入射光700 nm での外部磁界に対する $\theta_{\mathrm{K}}$ の変化を Figs. 8(a), 8 (b)に示す. Fig. 8(a) は薄膜表面から, Fig. 8(b)はガラス基 板側から光を入射した結果である。Fig. 8(a)より，プレス パッ夕 3 分と 60 分の試料の飽和 $\theta_{\mathrm{K}}$ 值はそれぞれ $0.05^{\circ}$ と $0.1^{\circ}$ 程 度であり，一般的な $\mathrm{TbFeCo}$ の飽和 $\theta_{\mathrm{K}}$ 值 $\left(0.3^{\circ}\right)^{10,13)}$ よりも小 さい.これは膜表面の各元素が部分的に酸化したことによる $\theta_{\mathrm{K}}$ の減少である. 特に〜 $700 \mathrm{~nm}$ 程度の長波長光を入射した 際の $\theta_{\mathrm{K}}$ は主に有効 Co 元素に支配されるため ${ }^{17)}$, Fig. $8(\mathrm{a})$ に 見られる理論值より小さな飽和 $\theta_{\mathrm{K}}$ 值は特に膜中の Co の一部 が酸化していることを示唆している.これは Fig. 5の XPS の 結果とも一致する。一方 Fig. 8(b)では， 3 分の試料は飽和 $\theta_{\mathrm{K}}$ 值が約 $0.04^{\circ}$ 程度となった。これは基板側からの測定結果であ り, 膜表面から膜厚 $65 \mathrm{~nm}$ の薄膜の基板付近まで $\mathrm{O}$ が拡散す るとは考えがたい，従って先に述べたように，酸化したター ゲットと Tb チップの清净化が不十分なまま成膜したために, 成膜の初期段階から薄膜中に $\mathrm{O}$ が混入して $\theta_{\mathrm{K}}$ 值が小さくなっ たと考察できる．プレスパッ夕時間による磁気光学特性の相 違は, 膜中の僅かな $\mathrm{O}$ 量の差異 (Fig. 7) によるものと考えら れる. Fig. 8(b)よりプレスパッタ60分の試料の飽和 $\theta_{\mathrm{K}}$ 值は $0.3^{\circ}$ 程度で, Kerr ヒステリシス曲線より $H_{c \perp}$ は $8.2 \mathrm{kOe}$ であっ た。大気曝露による酸化の影響を受けがたい基板側薄膜中の 

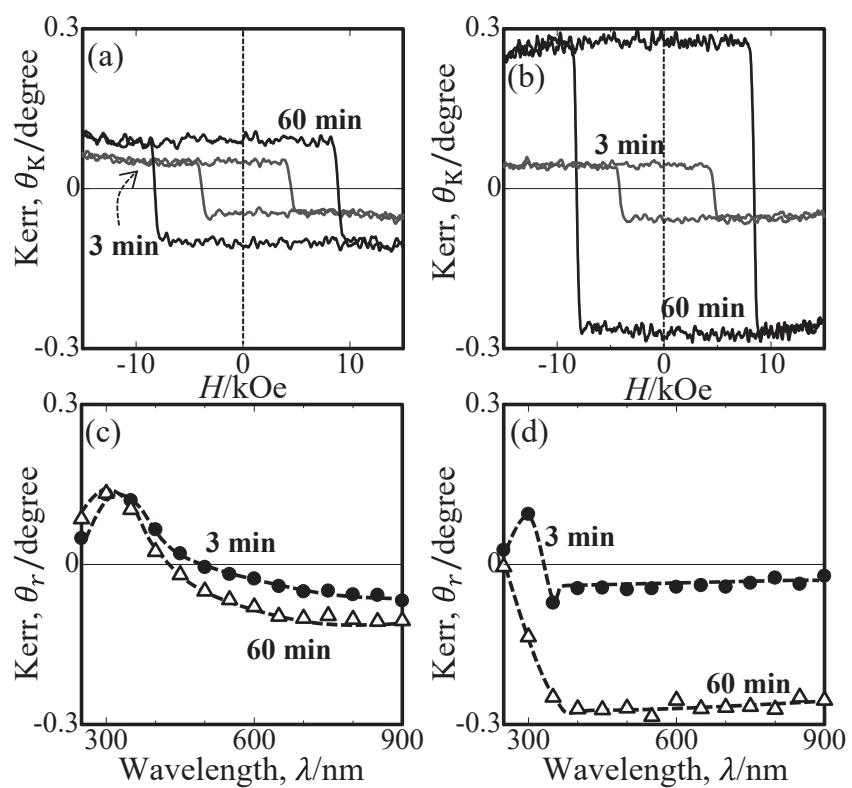

Fig. 8 Comparisons of the magneto-optical properties of TbFeCo films after 3 and 60 min of pre-sputtering. Polar Kerr hysteresis loops measured at (a) the film surface and (b) the substrate side at an incident light wavelength of $700 \mathrm{~nm}$. Changes in $\theta_{r}$ values as a function of incident light wavelength for measurements at (c) the film surface and (d) the substrate side.

元素は，60分のプレスパッ夕による十分な清浄化により O と 未結合の有効元素で構成されていると考察できる。これは膜 深部に抢いて O と未結合の純粋な金属元素が存在するXPSの 結果 (Fig. 5および Fig. 7) と一致している.

さらに外部印加磁界が 0 のときの $\theta_{\mathrm{K}}$ 值を $\theta_{r}$ と定義し, 波 長250 900 nm の入射光に対する $\theta_{r}$ の值を Figs. $8(\mathrm{c}) ， 8(\mathrm{~d})$ に示す。プレスパッタ 3 分 $($ ○および60分 $(\triangle)$ の試料の表面 (Fig. 8(c)) は，いずれも短波長側で極性が正で，波長 $450 \mathrm{~nm}$ で極性が負に転じた。これは薄膜表面に形成された酸化層に よる干渉効果の影響12)による $\theta_{r}$ の反転と考えられる。これに 対し基板側 (Fig. 8(d))では, プレスパッタ 3 分について Fig. 8 (c) と同様の傾向が見られた。プレスパッタ 3 分の試料は膜 表面と同様に350 $500 \mathrm{~nm}$ で $\theta_{r}$ の反転が見られ，基板側の膜 にも構成元素の部分的酸化による干渉効果の影響が見られる. 一方，プレスパッ夕60分の試料は $\theta_{r}$ の極性が常に負で, $\theta_{r}$ の 絶対值は波長 $400 \mathrm{~nm}$ 以上では $0.3^{\circ}$ であった。従ってプレス パッ夕60分の試料の基板側には膜中に $\mathrm{O}$ が非常に少なく, 構 成元素が $\mathrm{O}$ と未結合のため理論值である $0.3^{\circ}$ の $\theta_{r}$ が得られた と考えられる。

\section{4 有効元素量と磁気モーメントの相関に関する考察}

Fig. 2 (c) よりプレスパッ夕60分の試料の $H_{c \perp}$ は6.4 kOe であ り, 磁気光学特性から得られたこの試料の $H_{c \perp}$ の值 $(8.2 \mathrm{kOe})$ と異なる。両特性から得られた $H_{c \perp}$ の違いは, 薄膜全体の磁 気モーメントを評価するVSM と, 膜表面の反射光を評価す る Kerr 測定の違いによるものと考えられる。また Kerr ヒス テリシス曲線は磁気特性のヒステリシス曲線と反転した。こ の反転の原因としては, $\mathrm{TbFeCo}$ 薄膜の組成が(i) $3 d$ 元素 $(\mathrm{FeCo})$ が優位 ${ }^{10)}$, (ii) 4 f元素( $\left.\mathrm{Tb}\right)$ が優位 ${ }^{13)}$, (iii) 膜の不均質 が引き起こす異常ループ18)など様々な報告がこれまでになさ

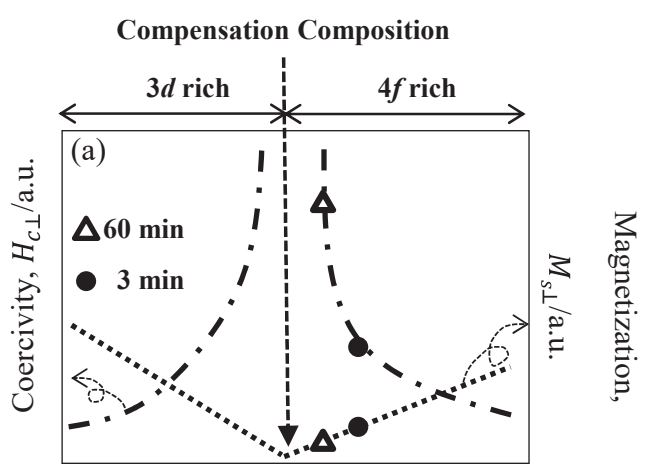

Effective Tb content, $x$

Compensation Composition

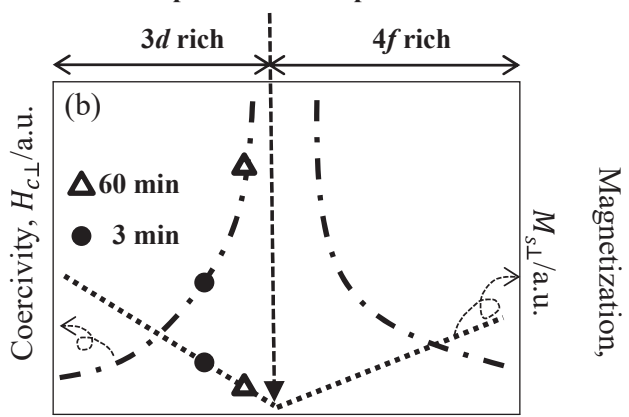

Effective Tb content, $x$

Fig. 9 Correlations between the out-of-plane coercivity $\left(H_{c \perp}\right)$, saturation magnetization $\left(M_{s \perp}\right)$, and the effective Tb content. The figures are based on Reference 3 ). The dash-dot lines indicate the behavior of $H_{c \perp}$ and the broken lines show $M_{s \perp}$. The compensation composition of $\mathrm{TbFeCo}$ is indicated by arrows. (a) represents the case when the effective $4 f(\mathrm{~Tb})$ magnetic moments are dominant in the film rather than the effective $3 d$ $(\mathrm{FeCo})$ magnetic moments. On the other hand, (b) represents the case when the effective $3 d$ magnetic moments are dominant in the film. $: 3$ and $\triangle: 60$ min of pre-sputtering in both figures.

れており，見解が一致していない，これに加え，本論文に結 果は示さないが, 我々の実験では同じチャンバー内に扔いて 同一ターゲットから同時に同条件下で成膜した $\mathrm{TbFeCo}$ 薄膜 でも，薄膜の下地構造の違いなどにより Kerr ヒステリシス 曲線の反転/非反転に差異があることを確認している。従っ て磁気光学特性のヒステリシス曲線の反転／非反転のみに基 づいて薄膜組成が $4 f$ 元素優位, あるいは $3 d$ 元素優位であると 結論するのは，必ずしも適切ではないと考える．Fig. 3(a)の 結果からは, 本研究で作製した試料は $4 f$ 元素の磁気モーメン 卜の方が $3 d$ 元素の磁気モーメントより優位な組成であると推 測されたが，ここではこれまでの議論から包括的に有効 $\mathrm{Tb}$ 量と磁気モーメントの関係について考察する.

プレスパッタ 3 分, 60 分の試料について, 有効 $\mathrm{Tb}$ 量に対 する $H_{c \perp}$ と $M_{s \perp}$ の相関を Figs. $9(\mathrm{a}) ， 9$ (b) に示す．Fig. 9(a) は本研究で作製した薄膜の有効 $4 f$ 元素 $(\mathrm{Tb})$ の磁気モーメント が優位な場合, Fig. 9 (b) は作製した薄膜の有効 $3 d$ 元素 $(\mathrm{Fe}$ と Co）の磁気モーメントが優位な場合を，それぞれ文献3)に基づ いて作成した，我々の試料について有効 $4 f$ 元素の方が優位と 仮定すると, プレスパッタ 3 分 $($ ) と60分 $(\triangle)$ の試料の磁気 特性を基にプロットした $H_{c \perp}$ および $M_{s \perp}$ は Fig. $9(\mathrm{a})$ となるは ずである。この場合, プレスパッタ 3 分の方が 60 分よりも有 効 $\mathrm{Tb}$ 量が多いことになるが、これまでの結果と議論より、プ 
レスパッタ 3 分の方が 60 分より有効 $\mathrm{Tb}$ 量が少ないのは明ら かである．従って Fig. 9(a)の相関は考えがたい，逆に試料の 有効 $3 d$ 元素の磁気モーメントの方が優位と仮定すると, Fig. 9(b)となる.この場合はプレスパッタ 60 分の方が 3 分より補 償組成に近く, 有効 $\mathrm{Tb}$ 量は60分の試料の方が多くなる. こ れは先に議論したこれまでの実験結果とも合致しており，本 研究で作製した試料は Fig. 9(b)の相関，すなわち $3 d$ 元素の磁 気モーメントの方が $4 f$ 元素の磁気モーメントよりも優位な組 成にあると考えられる.

従って Fig. 3(a) は膜中に存在する $\mathrm{Tb}$ の全体量, すなわち $\mathrm{Tb}_{2} \mathrm{O}_{3}$ の状態で存在する $\mathrm{Tb}$ 量と有効 $\mathrm{Tb}$ 量の合算值が 26 at $\%$ であることを示している. 26 at\%は補償組成よりも Tb 量が 多いため, Fig. 3(a)の結果のみを考えると $4 f$ 元素の磁気モー メントが優位になると予測された. しかし磁気特性, 磁気光 学効果, XPS の結果を総合的に考慮すると，プレスパッ夕 60 分の試料は有効 $\mathrm{Tb}$ 量が補償組成の $22 \mathrm{at} \%$ 近傍であり, Fig. 9 (b)の関係が成り立つと結論することができる.

\section{4. 結 論}

バッチ式一源スパッタ装置を用いて $\mathrm{TbFeCo}$ 薄膜を成膜す る際, 薄膜中の各元素の酸化状態が如何にプレスパッタに よって影響を受けるか, また磁気物性が構成元素の僅かな酸 化状態の違いによって多大な影響を受けることを実験的に明 らかにした．本研究では磁気特性と磁気光学特性およびXPS の結果を基に, 有効元素と磁気物性について詳細に議論した.

バッチ式一源スパッタ装置を用いた場合, 成膜前の十分な プレスパッタは, ターゲットと Tb チップ表面の清浄化に有 効であり， $M-H$ 曲線による $H_{c \perp}$ が $6.4 \mathrm{kOe}, \theta_{\mathrm{K}}-H$ 曲線によ る $H_{c \perp}$ が $8.2 \mathrm{kOe}$ の優れた垂直磁気異方性を示す補償近傍組 成の $\mathrm{TbFeCo}$ 薄膜の成膜条件を確立することができた。最適 なプレスパッタ時間は本研究の実験条件下では60分以上で あった. ターゲットと $\mathrm{Tb}$ チップの清浄化が不十分なまま成 膜すると, 特に $\mathrm{Tb}$ の一部が酸化されて $\mathrm{Tb}_{2} \mathrm{O}_{3}$ となり, その結 果として膜中の有効 $\mathrm{Tb}$ 量が減少して垂直磁気異方性が弱ま ることが明らかとなった

また非ロードロック式の簡便なバッチ式一源スパッタ装置 でも, 構成元素の酸化状態, すなわち有効元素量をプレス パッタのみで簡便に制御可能なことを示した.これはバッチ 式一源スパッ夕装置を用いても，プレスパッタにより磁気物
性を制御できることを示している，薄膜の酸化を抑制するこ とによって有効元素量の減少を抑制し, 補償近傍組成の高品 位な $\mathrm{TbFeCo}$ 薄膜を作製することができた，汎用性の高い簡 便な装置を用いて元素添加などの外因的な手段ではなく，プ レスパッタ条件の制御だけで再現性良く高品位な TbFeCo 薄 膜を成膜し，その磁気物性も制御することができれば，従来 にはない $\mathrm{TbFeCo}$ の新たな材料応用が拓けるものと考えられ る.

本研究は JSPS 科研費 JP16K06273の助成ならびに一般財団 法人田中貴金属記念財団の研究助成を受けました。また本研 究の一部は文部科学省ナノテクノロジープラットフォーム事 業(微細構造解析)の支援により, 東京大学で実施されました.

文 献

1) M. Y. Teng, C. Y. Hsu, K. S. Liu and I. N. Lin: J. Magn. Magn. Mater. 239(2002) 338-342.

2) T. Chen, D. Cheng and G. B. Charlan: IEEE Trans. Magn. Mag-16 (1980) 1194-1196.

3) M. Mochida and T. Suzuki: IEEE Trans. Magn. 38(2002)20962098.

4) M. T. Rahman, X. Liu, M. Matsumoto and A. Morisako: IEEE Trans. Magn. 41 (2005) 2568-2570.

5) D. Bang and H. Awano: J. Appl. Phys. 115(2014) 17D512.

6) S. Li, H. Nakamura, T. Kanazawa, X. Liu and A. Morisako: IEEE Trans. Magn. 46(2010) 1695-1698.

7) M. Nakayama, T. Kai, N. Shimomura, M. Amano, E. Kitagawa T. Nagase, M. Yoshikawa, T. Kishi, S. Ikegawa and H. Yoda: J. Appl. Phys. 103(2008) 07A710.

8) T. Iijima and I. Hatakeyama: IEEE Trans. Magn. MAG-23(1987) $2626-2628$

9) T. Niihara, F. Kirino, N. Ogihara, E. Koyama, R. Sudou, K. Shigematsu and N. Ohta: IEEE Trans. Magn. 24(1988) 24372442 .

10) T. Kanaizuka, T. Ohwada, Y. Morihara, T. Katayama and T. Suzuki: J. Magn. Soc. Jpn. 11 (1987)333-335.

11) T. K. Hatwar, A. C. Palumbo and D. G. Stinson: IEEE Trans. Magn. 24(1988) 2775-2777.

12) E. E. Marinero, D. C. Miller, A. E. Bell, A. Gupta, R. N. Payne and H. Notarys: IEEE Trans. Magn. MAG-23(1987) 2629-2631.

13) K. Wang, Y. Huang, Z. Xu, S. Dong and R. Chen: J. Magn. Magn. Mater. 424(2017) 89-92.

14) F. Kirino, N. Ohta and F. Kugiya: J. Japan Inst. Metals 58(1994) 359-367.

15) D. D. Sarma and C. N. R. Rao: J. Electron Spectrosc. Relat. Phenom. 20 (1980) 25-45.

16) C. Xu, Z. Chen, X. Yang, S. Li, D. Chen, S. Zhou and T. Lai: J. Magn. Magn. Mater. 324(2012) 2034-2038.

17) H. Tsujimoto, M. Shouji and Y. Sakurai: IEEE Trans. Magn. MAG-19(1983) 1757-1759.

18) T. Chen and R. Malmhäll: IEEE Trans. Magn. MAG-20 (1984) 1025-1026. 